\title{
A Critical Analysis Of Rising Intolerance And Growing Polarisation: Lynching
}

\author{
Rashmi Dubey, Ujjwala Sakhalkar
}

\begin{abstract}
Fear of law and veneration for the Scommand of the law constitutes the foundation of a civilized society...Lynching is an affront to the rule of law and to the exalted values of the Constitution itself. We may say without any fear of contradiction that lynching by unruly mobs and barbaric violence arising out of incitement and instigation cannot be allowed to become the order of the day."-Tehseen S.Poonawalav.Union of India

The term 'Law' do not just have a mere existence rather is being enacted and enforced for the betterment of the public at large. For benefits of the citizens various basic rights has been conferred upon them and accordingly their social behaviour is being regulated. Citizens in return is required to mandatorily abide by the enforced laws. From the era of divinity, the study of various religion has always laid emphasis on to the laid down norms to regulate the human conduct in the society. Law has been the crucial part of this man-made society. The very basic purpose of law is to keep a check upon the actions of the individual and to protect the society from various criminal activities. But Lynching, an act, comprising of violence which sets aside the laid down laws is gradually becoming a fear for the public at large. It signifies that people are seeking for instant justice for any form of crime thereby creating a threat to the existing laws which are meant to preserve and protect the society. Nothing else can define the act of Lynching in a best possible way then this statement given by Mahatma Gandhi: "an eye for an eye can turn the whole world blind."
\end{abstract}

Index Terms: Civilized Society, Citizens, Constitutional Law, Fair Trial, Mob Lynching.

\section{INTRODUCTION}

"...the law, the mightiest sovereign in a civilized society"

Krishnamoorthy v. Sivakumar and Ors.

A society can be said to be civilized only when it is governed by the proper statutory laws. The first and foremost purpose of the enactment of the law is to bring society in order where the citizen of the country can dream of reasonable freedom and progress. But along with the liberty always comes responsibility therefore every citizen is bound to follow the command of sovereign. Theauthority legislating and executing the law cannot be sullied simply because an individual or a group generate the attitude that they have been empowered by the principles set out in law to take its enforcement into their own hands and gradually become law unto themselves and punishthe individual.

The term lynch means "bringing life of person to an end for an alleged offence without abiding by the legal trial".

Revised Manuscript Received on April 19, 2019.

Rashmi Dubey, Asst. Prof. Bharati Vidyapeeth Deemed University, New Law College, Pune, Maharashtra, India.(Email: rashmi.law01@gmail.com)

Ujjwala Sakhalkar, Asst. Prof. Bharati Vidyapeeth Deemed University, New Law College, Pune, Maharashtra, India.(Email: shaikhag.1981@gmail.com)
Lynch law refers to a court constituted by the public themselveswhich imposes punishment on an individual without paying heed towards the due process of law. Lynching, an act of violence is becoming a menace for the society. This concept of Lynching has taken birth from human desire of having instant justice even for a trifling issue or onto the basis of preponderance of probabilities. Suchan act are also taking place because of the prejudiced mind of the individual or out of fear of future danger.

Lynching, called as "horrendous acts of mobocracy" has its origin in the United States. Over 200 anti-lynching bills are placed in the United States now. For the past 18 years, India also has witnessed a tremendous increase in the crime related to mob violence, and in the name of religion, kidnapping, rape etc. the act of lynching is being undertaken every now and then without giving any thought to the act.

Since a horde do not have any face so usually in dozens and in several hundred they dare to take law in their hand and consequently results in wrongdoing or say commits a heinous crime of extra-judicial killing. Such action, called as Lynching goes unnoticed and unpunished many a times. This mobocracy has its ambit from trifling issues viz., violation of prevailing local customs to serious crimes like theft, robbery, murder etc. In this act mob only serves as prosecutor, judge, jury and executioner.

The Supreme Court hasdemanded a stringent law to firmly deal with mob lynching and said that if action won't be taken such incidents may rise like a "a deadly creature or a monstrous serpentine giant"across the country and the globe.

A bench headed by Chief Justice Dipak Mishra had also passed a slew of directions to the government to provide "preventive, remedial and punitive measures" to deal with offences like mob violence and cow vigilantism.

"The State cannot turn a deaf ear to the growing rumblings of its people," the bench, comprising of Justices A.M. Khanwilkar and D.Y. Chandrachud, stated. The apex court said it is the need of the hour to enact such a stringent law that may create apprehension in the mind of the individuals involving themselves in the criminal act of mob lynching.

This intolerance which can be witnessed at a rapidly growing scale in the form of Lynching is creating a grave situation of chaos and anarchy among the citizen of the nation. Now the nation is duty-bound to act responsibly to 
protect and safeguard the constitutional and human rights of every person. Earnest action and concrete steps have to be taken to protect the citizens from the recurrent pattern of violence which cannot be allowed to become 'the new normal.'

\section{METHODOLOGY}

A summarization of the concept of 'Lynching' is doctrinal in approach.

i. Lynching is gradually becoming a serious threat towards the free existence of the mankind and therefore attracting the attention of the three organs of the Government.

ii. It is also heading towards the development of such society which is not being governed under any law. Therefore, thinkers, philosophers and eminent jurists are not putting their legs behind and are continuously giving directions related to the said issue.

iii. In Legal Courses such as LL.B and LL.M, various schools of Law and necessity of law for regulating the actions of the public at large, figures as a special paper for study.

Thus, it's the demand of the time and era to enact and introduce the stringent statutory law to curb the concept and practice of Lynching which to some extent has given birth to Intolerance and polarisation in the country. Law with its enactment requires immediate implementation and further introducing it as a part of syllabus in the Legal Course and through legal aid camps etc.

\section{FINDINGS}

Public Discussions, Conferences and Seminars organised by academic institutions are laying emphasis on to the issue of Lynching and analysing the need of the hour to tackle the situation of this extreme Intolerance.

- Reasons for the uncontrolled growth of such practice are being take into account and some of the reasons for such act are:

\section{i. Rise of cow vigilante-}

From the time the Government of the country has imposed ban on the sale and purchase of cattle for slaughtering purpose across India, under Prevention of Cruelty to Animals statutes (26th May 2017), it sparked a phase of cow vigilante in the nation thereby leading to mob attack.

\section{ii. Non-Involvement of political class-}

This rise in the mob violence has no impact on the political parties and bureaucrats and they opt to remain silent for the reason best known o them.

\section{iii. Child-Kidnapping Fear-}

The unnecessary rumours of child kidnappers proved to an ignition point for mob violence, where WhatsApp posts were circulated in Odisha, Tamil Nadu, Gujarat, Karnataka, Telangana, Tripura and West Bengal.

- Government initiatives on such issue can be discussed asawareness about such enacted law shall be done by

\section{A) Appointment of nodal officers}

The Government of India has instructed states to appoint a nodal officer in each district to prevent the incidents of mob violence and lynching. Home Ministry has directed state governments to implement the directions of the Supreme Court in letter and spirit. Further, the Ministryhas said that police are duty-bound to register FIR against persons who involves in igniting the act of Lynching by circulating the fake messages and videos through the social media i.e., Wats App.

\section{B) Formulation of Two high level committees}

The Government has lead to the establishment of 'Two high-level committees' to suggest appropriate measures and law to efficiently deal with the matters of mob violence and lynching.

- $\quad$ Provisions related to Lynching under codified laws of India -

\begin{tabular}{|c|c|}
\hline Indian Penal Code,1860 & $\begin{array}{cc}\text { Criminal } & \text { Procedure } \\
\text { Code,1973 } & \end{array}$ \\
\hline $\begin{array}{l}\text { 1. Section } \\
\text { 34:Common Intention }\end{array}$ & 1.Section 223(a) \\
\hline $\begin{array}{l}2 . \quad \text { Section } \\
\text { Conspiracy }\end{array}$ & 2.Section 144 \\
\hline $\begin{array}{l}\text { 3. Section } \\
\text { Unlawful Assembly }\end{array}$ & \\
\hline $\begin{array}{l}4 . \quad \text { Section } \\
147,148,149 \text { : Rioting }\end{array}$ & \\
\hline $\begin{array}{l}5 . \quad \text { Section 300/302: } \\
\text { Murder }\end{array}$ & \\
\hline $\begin{array}{lll}6 . & \text { Section } & 304: \\
\text { Culpable Homicide }\end{array}$ & \\
\hline $\begin{array}{l}7 . \quad \text { Section } \\
\text { 323:Punishment for } \\
\text { voluntarily causing hurt }\end{array}$ & \\
\hline $\begin{array}{l}\text { 8. Section } 325: \\
\text { Punishment for voluntarily } \\
\text { causing grievous hurt }\end{array}$ & \\
\hline
\end{tabular}

- Cross-Border Laws:

i. Dyer Anti-Lynching Law,1918

ii. The Anti-Lynching law of 1928 in Virginia

iii. Nigerians Anti-Lynching Bill, 2009

iv. United Nations Convention against Torture and Other Cruel, Inhuman and Degrading Treatment or Punishment through Legislations.

\section{RESULTS AND DISCUSSIONS}

Analysis of collected data signifies that the act of Lynching nowadays are taking place in many ways and for various objects. Lynching's ambit is not only extended till India rather has spread all over the world. The targeted victims are usually poor people, minorities or socially backward classes. Statistics of data are in table 1.1:- 


\begin{tabular}{|c|c|c|}
\hline State & \begin{tabular}{|l} 
Mob Violence \\
Related To \\
Child-Lifting \\
Rumours \\
\end{tabular} & \begin{tabular}{|l|} 
Deaths In Mob \\
Lynchings \\
Related To \\
Child-Lifting \\
Rumours \\
\end{tabular} \\
\hline West Bengal & 4 & 3 \\
\hline Tripura & 3 & 3 \\
\hline Telangana & 4 & 4 \\
\hline Tamil Nadu & 12 & 4 \\
\hline Rajasthan & 1 & 1 \\
\hline Odisha & 15 & 1 \\
\hline Manipur & 1 & 0 \\
\hline Maharashtra & 4 & 5 \\
\hline Madhya Pradesh & 1 & 0 \\
\hline Kerala & 1 & 0 \\
\hline Karnataka & 6 & 1 \\
\hline \begin{tabular}{|l|} 
Jharkhand \\
\end{tabular} & 2 & 7 \\
\hline Gujarat & 3 & 1 \\
\hline Chattisgarh & 1 & 0 \\
\hline Assam & 6 & 3 \\
\hline Andhra Pradesh & 5 & 0 \\
\hline Grand Total & 69 & 33 \\
\hline
\end{tabular}

Table 1.1

- $77 \%$ of the attacks are the result of menace of fake news.

\section{CONCLUSION}

"It may be true that the law cannot make a man love me, but it can stop him from lynching me, and I think that's pretty important."

\section{Martin Luther King Jr.}

Various fundamental rights has already been entrusted to the citizen especially Freedom of Speech and Expression but expressing through the mode of 'Lynching' is not justifiable. The emerging act of 'Lynching' is signifying that we are living in the era where sovereigns do not have control on their subjects. The Constitution is required to frame stringent legislation to control this extra-judicial homicide and to prevent this trend of pseudo instant justice.

\section{REFERENCES}

1. Tehseen S. Poonawalla v. Union of India(2018) 6 SC 72

2. Krishnamoorthy v. SivaKumar and Ors.(2015) 3 SCC 467(Supreme Court of India:2015)

3. Kodungallur Film Society and Ors. Vs. Union of India(UOI) and Ors.(2018) 10 SCC 713(Supreme Court of India:2018)

4. Satya Narain@Satpal vs. State of Rajasthan 2000(4) W.L.C.24(Supreme Court of India:2000)

5. S.Rangarajan v. P. Jagjivan Ram and Ors.(1989) 2 SCC 574.( Supreme Court of India:1989)

6. Najabhai Deshurbhai Wagh vs. Valerabhai Deganbhai Vagh and Ors. (2017) 2 SCC (Cri.)67 (Supreme of India;2017)

7. Vijay Pandurang Thakre and Ors. v. State of Maharashtra (2017) 4 SCC 377(Supreme Court of India:2017)

8. https://www.civilserviceindia.com/currentaffairs/articles/rising-mob-violence-in- india.html

9. https://indianexpress.com/article/india/supreme-courtasks-states-uts-to-comply-with-itsorder-on-cowvigilantism-mob-lynching-5372298/
10. https://sabrangindia.in/article/child-lifting-rumours-33killed-69-mob-attacks-jan-2017-only-1-attack-2012

11. http://www.indiaenvironmentportal.org.in/files/mob\%201 ynching\%20Supreme\%20Court\%20Judgement.pdf

12. https://www.google.co.in/search?q=final+project+4th+se $\mathrm{m}+$ LLM.docx $+(\mathrm{D} 51700113) \& \mathrm{tbm}=$ isch\&source $=$ univ\&s $\mathrm{a}=X \& v e d=2 \mathrm{ahUKEwjnue}-$ ym5vjAhUt6XMBHRFwAQQQsAR6BAgFEAE\&biw= $1366 \&$ bih $=657$

13. Dr. Bhagyashree Deshpande and Anuradha Girme, "Research Methods Made Simple", International Journal of Innovative Technology and Exploring Engineering, 2019.

14. Dr.Ujwala Bendale and Vidya Dhere, "Right of Aged Persons to Live with Dignity: A Socio-Legal Perspective", International Journal of Innovative Technology and Exploring Engineering, 2019.

15. Sukrut Deo and Dr. Sapna Deo, "Cyber squatting: Threat to Domain Name", International Journal of Innovative Technology and Exploring Engineering, 2019.

16. Ms. Vidya Dhere and Dr.Ujwala Bendale, "Impact of Smart City on Social Relations", International Journal of Innovative Technology and Exploring Engineering, 2019.

17. Anuradha Girme and Dr. Bhagyashree Deshpande, "The Life Line of Human Beings - Right to Potable Water", International Journal of Recent Technology and Engineering, 2019.

18. Sukrut Deo and Dr. Sapna Deo, "Domain Name and its Protection in India", International Journal of Recent Technology and Engineering, 2019.

19. Sarda, M., Deshpande, B., Dharm, J., Dhere, V., Different aspects of environmental laws , International Journal of Recent Technology and Engineering, 2019

20. Sarda, M., Deshpande, B., Deo, S., Karanjkar, A comparative study on Maslow's theory and Indian Ashrama system, International Journal of Innovative Technology and Exploring Engineering ,2018

21. Sarda, M., Deshpande, B., Shringarpure, S., Smart city Use of technology and the needed labor reforms, International Journal of Innovative Technology and Exploring Engineering, 2018

22. Anwesha Pathak and A. Mishra, "Human Trafficking In India", Journal of International Pharmaceutical Research, 2019

23. Rashmi Dubey and Ujjwala Sakhalkar, "A Critical Analysis of Rising Intolerance and Growing Polarisation: Lynching", Journal of International Pharmaceutical Research, 2019

24. Jayashree Khandare and Anisa Shaikh, "When life becomes death: a stifling story of air pollution", Journal of International Pharmaceutical Research, 2019 